\title{
Injeksi Kortikosteroid Intratimpani Sebagai Salvage Therapy pada Pasien Tuli Mendadak
}

\author{
Ricko Mariza Putra ${ }^{1}$, Jacky Munilson², Yan Edward², Nirza Warto², Rossy Rosalinda²
}

\begin{abstract}
Abstrak
Pendahuluan : Tuli mendadak merupakan salah satu kegawatdaruratan di bagian telinga hidung tenggorok bedah kepala dan leher (THT-KL). Tuli mendadak atau sudden sensorineural hearing loss (SSNHL) adalah tuli sensorineural lebih dari $30 \mathrm{~dB}$ pada 3 frekuensi berturut turut secara mendadak dalam waktu 3 hari. Etiologi tuli mendadak hingga saat ini belum diketahui dengan pasti, namun penyebab tersering tuli mendadak, yaitu idiopatik (71\%). Penatalaksanaan tuli mendadak meliputi terapi konservatif, salah satunya dengan pemberian kortikosteroid secara sistemik dan lokal. Pemberian lokal dapat dilakukan dengan cara injeksi langsung intratimpani. Terapi kortikosteroid secara lokal dapat diberikan sebagai terapi primer, terapi adjuvan (kombinasi) dan salvage therapy. Laporan kasus : seorang pasien perempuan berusia 36 tahun dengan diagnosis tuli mendadak pada telinga kanan yang dilakukan salvage therapy dengan penyuntikan deksametason intratimpani sebanyak empat kali secara selang 3 hari setelah gagal dengan terapi sistemik. Kesimpulan : Injeksi kortikosteroid intratimpani digunakan sebagai salvage therapy dapat menjadi pilihan untuk pasien yang gagal diterapi dengan kortikosteroid sistemik.
\end{abstract}

Kata kunci: tuli mendadak; salvage therapy; deksametason; intratimpani

\begin{abstract}
Introduction: Sudden deafness is one of the emergency in otorhinolaryngology head and neck surgery (ORLHNS). Sudden deafness or sudden sensorineural hearing loss (SSNHL) is sensorineural deafness of more than $30 \mathrm{~dB}$ at 3 frequencies within 3 days. The etiology of sudden deafness is recently remain unknown, but the most common cause of deafness is idiopathic (71\%). Management of sudden deafness includes conservative therapy, one of which is corticosteroids systemically and locally. Local delivery is done by intratympanic injection. Local corticosteroid therapy can be administered as primary therapy, adjuvant therapy (combination) or salvage therapy. Case report : a female patient aged 36 years old with diagnosis of sudden deafness at right ear which is performed salvage therapy with dexamethasone intratympanic injection four times with interval of 3 days after systemic therapy was failed. Conclusion : corticosteroid intratympanic injection as salvage therapy may be an option for patients who failed therapy with systemic corticosteroids.
\end{abstract}

Keywords: sudden deafness, salvage therapy, dexamethasone, intratympanic

Affiliasi penulis : ${ }^{1}$ Bagian THT-KL Fakultas Kedokteran Universitas Andalas, ${ }^{2}$ Bagian THT-KL Fakultas Kedokteran Universitas Andalas Korespondensi : Ricko Mariza Putra, dr.rickomp@yahoo.co.id Telp: 08111891391

\section{PENDAHULUAN}

Tuli mendadak merupakan salah satu kegawatdaruratan yang memerlukan penanganan segera, efektif dan tepat. Walaupun pada beberapa kepustakaan menyatakan bahwa tuli mendadak dapat mengalami pemulihan secara spontan, sekitar 32-70 \%. ${ }^{1}$ Etiologi tuli mendadak hingga saat ini belum diketahui dengan pasti, namun terdapat beberapa kemungkinan penyebab tuli mendadak, yaitu idiopatik $(71 \%)$, penyakit infeksi $(12,8 \%)$, penyakit telinga $(4,7 \%)$ seperti penyakit Meniere, otosklerosis, penyakit autoimun telinga bagian dalam, operasi telinga atau dasar otak, trauma $(4,2 \%)$, vaskular dan hematologik $(2,8 \%)$, neoplasma $(2,3 \%)$, serta penyebab lainnya $(2,2 \%))^{2,3}$ Derajat ketulian dapat bervariasi mulai dari ringan, sedang, sedang berat, berat dan sangat berat. Telinga yang terkena biasanya unilateral, hanya $1-5 \%$ kasus bilateral. ${ }^{4}$ Penatalaksanaan tuli mendadak meliputi terapi konservatif dengan beberapa modalitas. Penanganan harus dilakukan sedini mungkin karena penanganan yang terlambat akan menyebabkan tuli yang permanen. Pemberian kortikostreroid dapat dilakukan secara sistemik dan lokal. Kortikosteroid lokal dapat diberikan sebagai terapi primer, adjuvan terapi dan salvage therapy.

\section{Anatomi vaskularisasi telinga dalam}

Vaskularisasi telinga dalam berasal dari a. labirintin yang merupakan cabang dari a. cerebelaris anteroinferior. Arteri ini masuk ke meatus akustikus internus dan bercabang menjadi a. vestibularis anterior dan a. koklearis communis yang kemudian akan bercabang menjadi a. kohlearis dan a. vestibulokohlearis. Arteri vestibularis anterior memperdarahi $n$. vestibularis, urtikulus dan sebagian duktus semisirkularis. Sedangkan a. vestibulokoklearis sampai di mediolus daerah putaran basal koklea bercabang menjadi cabang terminal vestibularis dan cabang kohlear. ${ }^{7}$ 
Cabang vestibular memperdarahi sakulus, sebagian besar kanalis semisirkularis dan ujung basal kohlea. Cabang kohlear memperdarahi ganglion spiralis, lamina spiralis ossea, limbus dan ligamen spiralis. a. koklearis berjalan mengitari $n$. akustikus di kanalis akustikus internus dan di dalam kohlea mengitari modiolus ${ }^{7}$ (Gambar 1).

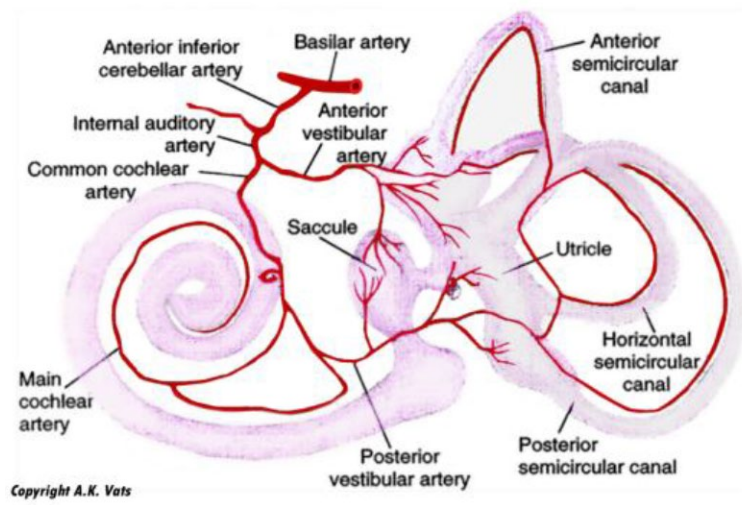

Gambar 1. Vaskularisasi telinga dalam

\section{Definisi dan Epidemiologi}

Tuli mendadak atau sudden deafness atau sudden sensorineural hearing loss (SSNHL) adalah hilangnya pendengaran sensorineural yang lebih dari $30 \mathrm{~dB}$ pada 3 frekuensi berturut turut secara mendadak dalam waktu 3 hari, sering unilateral dan idiopatik. Insiden kasus tuli mendadak berkisar 5-20 orang tiap 100.000 orang pertahun. ${ }^{1,4}$

Penderita tuli mendadak mencapai $1 \%$ dari seluruh penderita ketulian di seluruh dunia, dengan 15.000 kasus baru setiap tahunnya. ${ }^{8}$ Distribusi kejadian antara laki-laki dan perempuan hampir sama, dengan puncak usia 40-54 tahun. ${ }^{4}$ Sedangkan menurut Fedriani puncak usia 50-60 tahun. ${ }^{8}$ Telinga yang terkena sebagian besar satu telinga (unilateral), dan hanya $1-5 \%$ kasus yang terjadi pada kedua telinga (bilateral). ${ }^{4}$

\section{Etiopatogenesis}

Penyebab tuli mendadak hingga saat ini belum diketahui dengan pasti, namun banyak teori yang mengemukakan faktor resiko penyebab terjadinya tuli mendadak. Sekitar $10-15 \%$ penyebab tuli mendadak yang dapat teridentifikasi. ${ }^{4,8}$ Empat teori utama yang dapat menjelaskan terjadinya tuli mendadak diantaranya infeksi virus, gangguan pembuluh darah, ruptur membran intra koklea dan penyakit autoimun telinga dalam. ${ }^{4}$

\section{Diagnosis}

Diagnosis ditegakkan berdasarkan anamnesis, pemeriksaan fisik, audiometri dan pemeriksaan penunjang lainnya. Anamnesis didapatkan hingga $80 \%$ datang dengan keluhan telinga penuh. Tinitus terjadi pada sekitar $80 \%$ pasien dan vertigo $30 \%$. Pemeriksaan fisik umum, seperti tekanan darah, nadi, nafas, suhu serta pemeriksaan lokalis THT-KL. Pasien dengan tuli sensorineural hampir selalu memiliki pemeriksaan otoskopi yang normal. ${ }^{9,10}$ Pemeriksan pendengaran dengan penala didapatkan Rinne positif, Weber lateralisasi ke telinga yang sehat, Schwabach memendek. Pada audiometri nada murni didapatkan tuli sensorineural ringan hingga sangat berat. $^{9-11}$ Tuli mendadak juga dapat dievaluasi dengan speech reception threshold, speech discrimination score, refleks stapedius, timpanogram dan tone decay. ${ }^{11}$ Pemeriksaan penunjang lainnya dapat juga diperiksa seperti pada (Tabel 1)

Tabel 1. Pemeriksaan laboratorium dan pencitraan ${ }^{4}$

\begin{tabular}{|c|c|}
\hline Test & Tujuan \\
\hline $\begin{array}{l}\text { Darah lengkap } \\
\text { dengan } \\
\text { differensial }\end{array}$ & $\begin{array}{l}\text { Polisitemia, leukemia, } \\
\text { trombositosis }\end{array}$ \\
\hline $\begin{array}{c}\text { Tingkat } \\
\text { sedimentasi, LED }\end{array}$ & $\begin{array}{l}\text { Skrining penyakit auto immun } \\
\text { atau inflamasi, diikuti dengan test }\end{array}$ \\
\hline Tes koagulasi & $\begin{array}{c}\text { Koagulopati (jika ada indikasi, } \\
\text { atau riwayat) }\end{array}$ \\
\hline Tes fungsi tiroid & $\begin{array}{c}\text { Hypothyroidism (jika ada indikasi, } \\
\text { atau riwayat) }\end{array}$ \\
\hline $\begin{array}{l}\text { FTA-Abs atau } \\
\text { MHA-TP }\end{array}$ & $\begin{array}{l}\text { Tes antibodi, Treponema } \\
\text { pallidum, kongenital atau didapat }\end{array}$ \\
\hline MRI & $\begin{array}{l}\text { Lesi Retrocochlear, multiple } \\
\text { sclerosis, perdarahan intra koklea }\end{array}$ \\
\hline $\begin{array}{l}\text { Tomografi } \\
\text { komputer }\end{array}$ & $\begin{array}{c}\text { kelainan kapsul otic pada pasien } \\
\text { pediatrik }\end{array}$ \\
\hline
\end{tabular}

$68 \mathrm{KD} \mathrm{Ab}, 68$ kiloDalton antibodi; ANA. antibodi antinuclear; FTA-Abs,Fluorescent treponemal anibodyabsoption test ; MHA-TP. microhemagglutinationTreponema pallidum

\section{Penatalaksanaan}

Pengobatan tuli mendadak idealnya didasarkan pada penyebabnya tetapi umumnya bersifat idiopatik, sehingga pengobatan dilakukan secara empiris. Terapi tuli mendadak umumnya berupa steroid sistemik, vasodilator (histamin, papaverin, verapamil, carbogen), hemodilusi (dextran, pentoxifylline, manitol, dan heparin), atau antiviral (acyclovir, valacyclovir). Terapi lainnya dapat berupa oksigen hiperbarik 100\% 2 hingga 2,5 ATA selama 90 menit setiap hari selama $10-20$ kali terapi. Selain itu, pasien dianjurkan tirah baring selama 2 minggu, diet rendah garam dan rendah kolesterol, penggunaan neurotonik, vitamin $\mathrm{C}$, vitamin $\mathrm{E}$, dan preparat herbal (gingko biloba). ${ }^{8,9}$

Pemberian kortikosteroid pada kasus tuli mendadak bervariasi dari segi jenis, dosis maupun teknik pemberian (Tabel 2) :

a. Terapi kortikosteroid sistemik

Kortikosteroid sistemik yang paling sering digunakan antara lain prednison, metilprednisolon dan deksametason. Prednison diberikan dengan dosis 1 $\mathrm{mg} / \mathrm{kg}$ berat badan/hari atau maksimal $60 \mathrm{mg} / \mathrm{hari}$ tapering off selama 12-15 hari. Metilprednisolon diberikan dengan dosis $48 \mathrm{mg}$ tapering off. Deksametason diberikan dengan dosis $10 \mathrm{mg} / \mathrm{hari}$ tapering off. Efek samping yang ditimbulkan penggunaan kortikosteroid antara lain insomnia, dizziness, gastritis, kenaikan berat badan, berkeringat, 
perubahan mood, hiperglikemia dan fotosensitif. Efek samping yang cukup berat, tetapi jarang ditemukan yakni pankreatitis, perdarahan, hipertensi, katarak, miopati, infeksi oportunistik, osteoporosis, dan osteonekrosis. ${ }^{2}$ Pasien dengan kondisi medis sistemik, seperti insulin-dependent diabetes mellitus (IDDM), diabetes tidak terkontrol, hipertensi labil, tuberkulosis, dan ulkus peptikum tidak diajurkan terapi kortikosteroid sistemik. ${ }^{2}$

b. Terapi kortikosteroid intratimpani

Injeksi kortikosteroid intratimpani pertama kali dilaporkan penggunaannya oleh Itoh (1991) untuk pengobatan penyakit telinga bagian dalam pada pasien dengan Penyakit Meniere. Pada kasus tuli mendadak terapi kortikosteroid intratimpani pertama kali dilaporkan oleh Silverstein (1996). Meskipun efektifitasnya belum terbukti secara definitif, terapi kortikosteroid intratimpani untuk tuli sensorineural menjadi lebih banyak digunakan. 5,6

Protokol pengobatan tuli mendadak dengan kortikosteroid intratimpani terdiri dari:5,6,8,9

- Terapi Primer; terapi intratimpani sebagai pengobatan pertama untuk tuli mendadak, tanpa kortikosteroid sistemik

- Terapi Adjuvan; terapi diberikan bersamaan dengan sistemik kortikosteroid

- Salvage therapy: terapi dimulai setelah terapi kortikosteroid sistemik gagal.

Pemberian kortikosteroid intratimpani sebagai terapi primer biasanya pada kelompok pasien yang tidak bisa mentolerir efek samping sistemik dosis tinggi dari terapi kortikosteroid sistemik, seperti pasien diabetes atau tekanan darah tinggi yang sulit untuk dikontrol. Sebuah studi mengenai terapi kombinasi kortikosteroid sistemik dosis tinggi dan kortikosteroid intratimpani menunjukkan hasil perbaikan fungsi pendengaran secara signifikan. Namun, studi lainnya tidak menghasilkan perbedaan pemulihan pendengaran antara terapi kombinasi kortikosteroid oral dan intratimpani dengan terapi kortikosteroid oral saja. ${ }^{12}$ Kebanyakan penggunaan kortikosteroid intratimpani dilakukan setelah pengobatan tuli mendadak menggunakan kortikosteroid sistemik gagal.

Jumlah yang disuntikkan antara 0,3-0,5 ml, sesuai dengan perkiraan volume ruang telinga tengah. Normalnya pada dewasa volume telinga tengah 0,6 1,5 ml. Periode waktu dan jumlah penyuntikan juga berbeda-beda yang bervariasi mulai dari 3 hari sampai 7 hari selama 3 sampai 4 kali pemberian (Tabel 2).8,9 Metoda yang dilakukan juga bervariasi : penyuntikan melalui membran timpani langsung dengan jarum suntik (Gambar 2a), melalui miringotomi dengan tabung (grommet) (Gambar 2b), menggunakan pipa (wick) yang diletakkan pada miringotomi (Gambar 2c), atau melalui pompa yang ditanamkan untuk mengantarkan steroid secara konstan (Gambar 2d). ${ }^{13}$
Tabel 2. Pedoman umum terapi kortikosteroid pda tuli mendadak

\begin{tabular}{|c|c|c|}
\hline & $\begin{array}{c}\text { Oral } \\
\text { Kortikosteroid }\end{array}$ & $\begin{array}{l}\text { Intratimpani } \\
\text { Kortikosteroid }\end{array}$ \\
\hline $\begin{array}{l}\text { Waktu } \\
\text { pengobatan }\end{array}$ & $\begin{array}{l}\text { Segera, } \leq 14 \\
\text { hari pertama. } \\
\text { Keberhasilan } \\
\text { dilaporkan } \\
\text { hingga } 6 \\
\text { minggu onset } \\
\text { tuli mendadak }\end{array}$ & $\begin{array}{l}\text { Segera, } \\
\text { Salvage (rescue) } \\
\text { setelah pengobatan } \\
\text { sistemik gagal }\end{array}$ \\
\hline Dosis & $\begin{array}{l}\text { Prednison } \\
1 \mathrm{mg} / \mathrm{kg} / \mathrm{hr} \\
\text { (maks } 60 \mathrm{mg} / \mathrm{hr} \text { ) } \\
\text { atau } \\
\text { Methylprednisol } \\
\text { one } 48 \mathrm{mg} / \mathrm{hr} \\
\text { atau } \\
\text { Deksametason } \\
10 \mathrm{mg} / \mathrm{hr}\end{array}$ & $\begin{array}{l}\text { Dexamethasone } \\
24 \mathrm{mg} / \mathrm{ml} \text { atau } 16 \\
\mathrm{mg} / \mathrm{ml} \text { (ditambah), } \\
\text { atau } 10 \mathrm{mg} / \mathrm{ml} \\
\text { (stok) } \\
\text { Methylprednisolone } \\
40 \mathrm{mg} / \mathrm{ml} \text { atau } 30 \\
\mathrm{mg} / \mathrm{ml}\end{array}$ \\
\hline $\begin{array}{l}\text { Durasi/ } \\
\text { frekuensi }\end{array}$ & $\begin{array}{l}\text { Dosis penuh } \\
\text { selama } 7-14 \\
\text { hari, dilanjutkan } \\
\text { dengan } \\
\text { tappering }\end{array}$ & $\begin{array}{l}\text { Injeksi } 0,4-0,8 \mathrm{ml} \\
\text { ke telinga tengah } \\
\text { setiap 3-7 hari } \\
\text { untuk 3-4 sesi }\end{array}$ \\
\hline Teknik & $\begin{array}{l}\text { Jangan } \\
\text { membagi dosis }\end{array}$ & $\begin{array}{l}\text { Diberikan obat bius } \\
\text { topikal, lalu } \\
\text { penyuntikkan ke } \\
\text { kuadran posterior } \\
\text { inferior dengan } \\
\text { jarum suntik untuk } \\
\text { mengisi ruang } \\
\text { telinga tengah. } \\
\text { Kepala posisi } \\
\text { otologic (telinga } \\
\text { yang sakit berada } \\
\text { diatas) selama 15- } \\
30 \text { menit }\end{array}$ \\
\hline Pemantauan & $\begin{array}{l}\text { Audiogram : } \\
\text { Setelah selesai } \\
\text { pengobatan dan } \\
\text { pada delayed } \\
\text { interval }\end{array}$ & $\begin{array}{l}\text { Audiogram : } \\
\text { Sebelum setiap } \\
\text { suntikan, setelah } \\
\text { selesai pengobatan } \\
\text { dan pada delayed } \\
\text { interval } \\
\text { Periksa membran } \\
\text { timpani (TM) untuk } \\
\text { memastikan } \\
\text { penyembuhan } \\
\text { setelah selesai } \\
\text { pengobatan dan } \\
\text { pada delayed } \\
\text { interval }\end{array}$ \\
\hline Modifikasi & $\begin{array}{l}\text { Efek samping } \\
\text { seperti insomnia } \\
\text { Memantau } \\
\text { hiperglikemia, } \\
\text { dan hipertensi } \\
\text { pada pasien } \\
\text { yang rentan }\end{array}$ & $\begin{array}{l}\text { Dapat dipasang } \\
\text { tabung bertekanan } \\
\text { jika direncanakan } \\
\text { beberapa kali } \\
\text { suntikan, tetapi } \\
\text { meningkatkan risiko } \\
\text { perforasi membran } \\
\text { timpani } \\
\text { Dapat juga } \\
\text { dipertimbangkan } \\
\text { menambahkan jalur } \\
\text { transportasi jendela } \\
\text { bundar }\end{array}$ \\
\hline
\end{tabular}




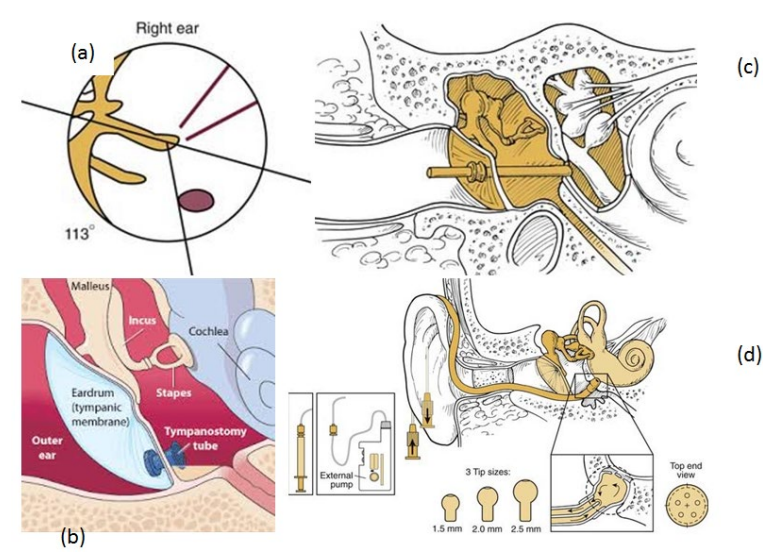

Gambar 2. Metoda penyuntikan (a) membran timpani langsung dengan jarum suntik (b) melalui tabung (grommet), (c) menggunakan pipa (wick), (d) melalui pompa yang ditanamkan.

\section{Prognosis}

Prognosis dan keberhasilan penatalaksanaan tuli mendadak dipengaruhi oleh beberapa faktor diantaranya usia, onset kehilangan pendengaran, derajat ketulian, jenis audiogram pertama ada tidaknya vertigo, ada tidaknya tinnitus, respon 2 minggu pengobatan pertama, dan adanya faktor predisposisi. ${ }^{2,4,11}$

Derajat ketulian menurut ISO diklasifikasikan sebagai ringan (>25-40), sedang (>40-55), sedang berat $(>55-70)$, berat $(>70-90)$, sangat berat $(>90)$, sesuai rata-rata nada murni pada frekuensi $500 \mathrm{~Hz}$, $1000 \mathrm{~Hz}, 2000 \mathrm{~Hz}, 4000 \mathrm{~Hz} .{ }^{10}$ Semakin berat derajat ketulian maka prognosis menjadi lebih rendah. ${ }^{14}$ Tipe kehilangan pendengaran diklasifikasikan menjadi 4 kelompok yaitu ascending type (frekuensi $250-500 \mathrm{~Hz}$ ), descending type (frekuensi 4000-8000), flat type $(<20 \mathrm{~dB}$ perbedaan antara yg terbaik dan terburuk), total atau sub total $(>85 \mathrm{~dB}) .{ }^{14}$ Ascending type memiliki prognosis yang lebih baik bila dibandingkan dengan descending, flat serta total atau sub total. Sedangkan menurut Atay pembagian tipe kehilangan pendengaran terdiri dari upward-sloping type (gangguan lebih berat pada frekuensi rendah), downward-sloping type (gangguanlebih berat pada frekuensi tinggi), flat type (tidak lebih dari $10 \mathrm{~dB}$ dari ambang dengar) dan profound type (lebih dari $70 \mathrm{~dB}$ pada semua frekuensi). ${ }^{1}$ Awal mulai pengobatan oleh Kasaplogu dkk dibagi menjadi 2 kelompok yaitu early (5 hari pertama), late (hari ke 5-15). ${ }^{14}$ Pengobatan dimulai kurang dari lima hari akan memberikan hasil yang lebih baik. Vertigo dapat digunakan sebagai indikator tingkat keparahan lesi dan berhubungan dengan prognosis pengobatan yang rendah. Menurut Kasaplogu menyimpulkan hasil penelitian Danino bahwa adanya gejala tinitus mempengaruhi reversibilitas hingga $80 \%$. Usia lanjut, hipertensi, diabetes dan hiperlipidemia berkaitan dengan disfungsi mikrovaskuler di koklea yang akan memperburuk prognosis kesembuhan. ${ }^{1,11,14}$

Namun pasien tuli mendadak yang tidak diobati dapat juga mengalami pemulihan spontan.
Menurut Jones seperti yang dikutip oleh Conlin menyatakan tuli mendadak dapat mengalami pemulihan spontan sekitar $32-70 \%{ }^{15}$ Menurut Matox seperti yang dikutip oleh Kasapoglu menyatakan sekitar $65 \%$ kasus tuli mendadak terjadi pemulihan spontan, sedangkan Battaglia menyatakan sekitar $32-64 \%$ tuli mendadak dapat mengalami pemulihan spontan. ${ }^{14}$

Evaluasi fungsi pendengaran dilakukan setiap minggu selama satu bulan. Kriteria perbaikan pendengaran menurut Kallinen: Sangat baik, apabila perbaikan lebih dari $30 \mathrm{~dB}$ pada 5 frekuensi. Sembuh, apabila perbaikan ambang pendengaran kurang dari $30 \mathrm{~dB}$ pada frekuensi $250 \mathrm{~Hz}, 500 \mathrm{~Hz}, 1000 \mathrm{~Hz}, 2000$ $\mathrm{Hz}$ dan di bawah $25 \mathrm{~dB}$ pada frekuensi $4000 \mathrm{~Hz}$. Baik, apabila rerata perbaikan $10-30 \mathrm{~dB}$ pada 5 frekuensi. Tidak ada perbaikan, apabila terdapat perbaikan kurang dari $10 \mathrm{~dB}$ pada 5 frekuensi. ${ }^{11}$

Evaluasi menurut Ho seperti yang dikutip oleh Filipo menyatakan pembagian evaluasi menjadi 4 kelompok yaitu pulih total dengan ambang dengar kurang dari $25 \mathrm{~dB}$, pulih bermakna dengan peningkatan ambang dengar lebih dari $30 \mathrm{~dB}$, pulih minimal dengan peningkatan ambang dengar sekitar 10-30 dB, dan tidak terjadi pemulihan dengan peningkatan ambang dengar kurang dari $10 \mathrm{~dB} .{ }^{16}$ Sedangkan Siegel seperti yang dikutip oleh Ferri dkk membagi kriteria perbaikan pendengaran setelah 3 bulan terapi menjadi : sembuh sempurna bila perbaikan lebih dari $30 \mathrm{~dB}$ dan pendengaran lebih baik dari $25 \mathrm{~dB}$, penyembuhan parsial bila perbaikan lebih dari $15 \mathrm{~dB}$ dan pendengaran antara 25-45 dB, penyembuhan ringan (slight) bila perbaikan lebih dari $15 \mathrm{~dB}$ tetapi pendengaran lebih buruk dari $45 \mathrm{~dB}$, tidak ada perbaikan bila perbaikan kurang dari $15 \mathrm{~dB}$ dan pendengaran lebih buruk dari $75 \mathrm{~dB} .^{17}$

\section{LAPORAN KASUS}

Seorang pasien perempuan usia 36 tahun datang ke IGD RSUP dr. M. Djamil Padang dengan keluhan telinga kanan tiba-tiba tidak dapat mendengar sejak 2 hari yang lalu. Keluhan ini dirasakan saat pasien bangun tidur. Telinga kanan dirasakan berdenging kadang bergemuruh sejak kejadian dan terus menerus. Pasien sudah berobat ke Spesialis THT-KL di klinik swasta di kota Padang dan telah dilakukan pemeriksaan audiometri serta disarankan untuk dirawat. Riwayat kedua telinga berair sebelumnya tidak ada, nyeri pada kedua telinga tidak ada, riwayat trauma tidak ada, riwayat terpapar bising tidak ada. Riwayat demam, batuk dan pilek tidak ada. Pusing berputar tidak ada. Riwayat sakit kepala hebat tidak ada. Riwayat diabetes dan tekanan darah tinggi tidak ada. Riwayat stroke dan penyakit jantung tidak ada. Pasien bekerja sebagai staf di kantor notaris. Satu minggu terakhir pasien bekerja lembur.

Pemeriksaan status generalis didapatkan keadaan umum sedang, kesadaran komposmentis kooperatif, frekuensi nafas 18 kali permenit, frekuensi nadi 80 kali permenit, tekanan darah 120/80 mmHg 
dan suhu $36,9^{\circ} \mathrm{C}$, Berat badan $65 \mathrm{Kg}$. Pemeriksaan telinga kanan dan kiri didapatkan liang telinga lapang, membran timpani utuh, refleks cahaya positif. Tes penala didapatkan Rinne positif pada telinga kanan dan kiri, Weber lateralisasi ke kiri, Schwabach telinga kanan memendek, telinga kiri sama dengan pemeriksa. Kesan tuli sensorineural pada telinga kanan. Pada pemeriksaan hidung dan tenggorok dalam batas normal.

Tes keseimbangan sederhana dapat dilakukan. Pemeriksaan audiometri nada murni didapatkan kesan telinga kanan tuli sensorineural derajat sangat berat dengan ambang dengar $103,75 \mathrm{~dB}$ dan telinga kiri normal dengan ambang dengar 11,25 dB (Gambar 3).

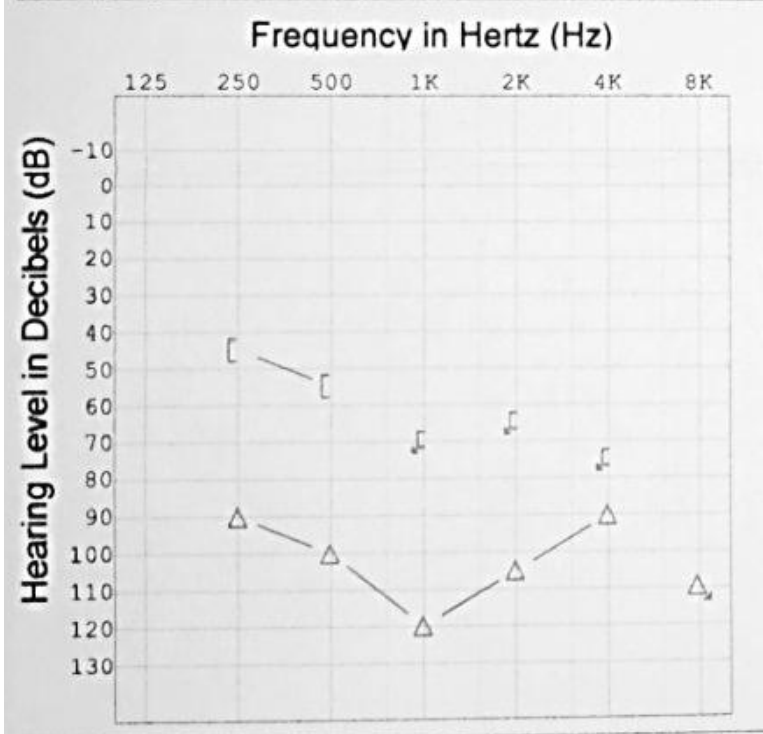

Gambar 3. Audiogram saat pasien masuk, Tuli sensorineural derajat sangat berat dengan ambang dengar 103,75 dB pada telinga kanan

Hasil pemeriksaan laboratorium darah

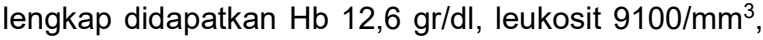
trombosit $279.000 / \mathrm{mm}^{3}$, hematokrit $39 \%$, PT 8,9", APTT 31,2", INR 0,8, gula darah sewaktu $136 \mathrm{mg} / \mathrm{dl}$, kolesterol total $185 \mathrm{mg} / \mathrm{dl}$, HDL $55 \mathrm{mg} / \mathrm{dl}$, LDL 120 $\mathrm{mg} / \mathrm{dl}$, trigliserida $52 \mathrm{mg} / \mathrm{dl}$, ureum $24 \mathrm{mg} / \mathrm{dl}$, kreatinin $0,6 \mathrm{mg} / \mathrm{dl}$, natrium $139 \mathrm{mmol} / \mathrm{dl}$, kalium 3,6 mmol/dl, klorida $105 \mathrm{mmol} / \mathrm{dl}$, SGOT $11 \mathrm{u} / \mathrm{L}$, SGPT $10 \mathrm{u} / \mathrm{L}$. Kesan : PT memendek. Pasien didiagnosis dengan tuli mendadak telinga kanan dengan hiperkoagulasi.

Pasien dirawat dan diberi terapi sesuai protap tuli mendadak di bagian THT-KL FK Unand RSUP. Dr. M. Djamil Padang yaitu oksigen intranasal 4 liter permenit selama 15 menit tiap 6 jam, metilprednison tablet $16 \mathrm{mg}$ peroral tappering off dengan dosis hari IIII dosis $1 \times 4$ tablet, hari IV-VI dosis $1 \times 3$ tablet, hari VII-IX dosis $1 \times 2$ tablet, hari X-XII dosis $1 \times 1$ tablet. Drip pentoksifilin $300 \mathrm{mg}$ dalam RL $500 \mathrm{cc}$ selama 8 jam, injeksi mekobalamin 3 × $500 \mathrm{mcg}$ IV, injeksi vitamin C $3 \times 100 \mathrm{mg} \mathrm{IV}$, gingko biloba $2 \times 80 \mathrm{mg}$ peroral, lanzoprazol $1 \times 1$ tablet peroral. Pasien dianjurkan istirahat total. Pasien dikonsulkan ke dokter spesialis penyakit dalam untuk hiperkoagulasi dan dari bagian penyakit dalam pasien diterapi dengan heparin $2 \times 5000 \mathrm{sc}$.

Hari ke-4 rawatan, pasien masih mengeluhkan kurang pendengaran, telinga berdenging belum berkurang, demam tidak ada, pusing berputar tidak ada, mual muntah tidak ada, nyeri ulu hati tidak ada. Tanda vital dalam batas normal. Tes penala 512 $\mathrm{Hz}$ didapatkan Rinne positif pada telinga kanan dan telinga kiri, Weber lateralisasi ke kiri, Schwabach telinga kanan memendek dan kiri normal. Kesan tuli sensorineural pada telinga kanan. Terapi diteruskan.

Hari ke-10 rawatan, pasien masih mengeluhkan kurangnya pendengaran, telinga berdenging berkurang, pusing tidak ada, demam tidak ada, mual muntah tidak ada, nyeri ulu hati tidak ada, merah pada wajah tidak ada. Tanda vital dalam batas normal. Tes penala didapatkan Rinne positif pada telinga kanan dan telinga kiri, Weber lateralisasi ke kiri, Schwabach telinga kanan memendek dan kiri normal. Kesan tuli sensorineural pada telinga kanan. Pemeriksaan audiometri nada murni didapatkan telinga kanan tuli sensorineural derajat sangat berat dengan ambang dengar 97,5 dB (gambar 4).

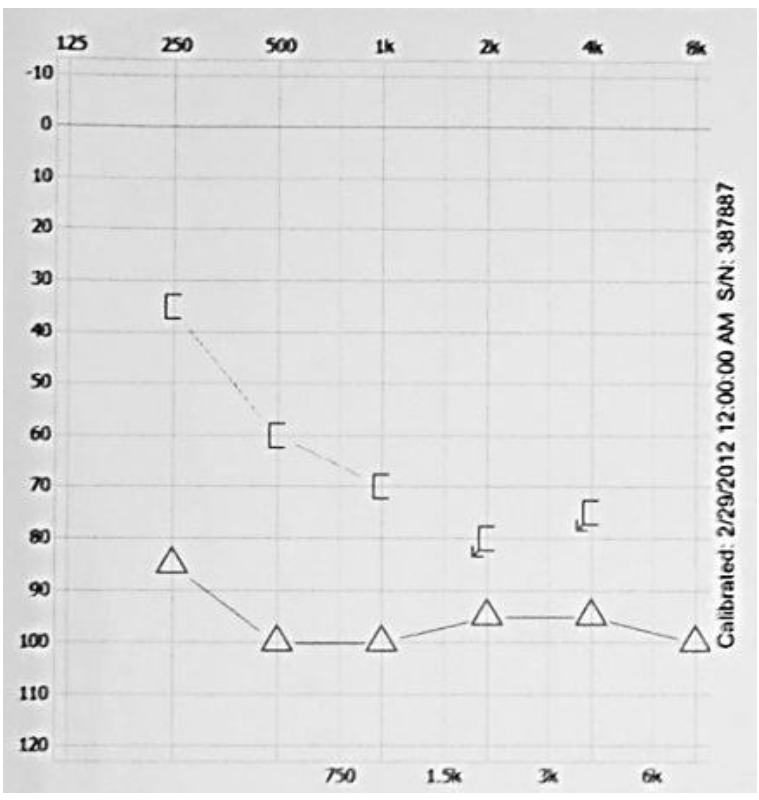

Gambar 4. Audiogram hari ke-10 rawatan, Tuli sensorineural derajat sangat berat dengan ambang dengar 97,5 dB pada telinga kanan

Hasil audiometri mengambarkan adanya perbaikan sebesar 6,25 dB. Hasil laboratorium ulang PT 9,9', APTT 29,3', INR 0,93, kesan normal. Pasien minta rawat jalan karena alasan keluarga. Terapi metilprednison tapering off diteruskan, mekobalamin 3 x $500 \mathrm{mg}$ peroral, pentoksifilin 3 x $400 \mathrm{mg}$ peroral, neurobion $1 \times 1$ tablet peroral, vitamin C $3 \times 100 \mathrm{mg}$ peroral, gingko biloba $2 \times 80 \mathrm{mg}$ peroral. Terapi heparin dihentikan. Pasien disarankan tetap istirahat total dirumah dan dianjurkan kontrol 5 hari lagi.

Pengobatan hari ke-15, pasien kontrol ke poli THT-KL. Pasien masih merasakan kurangnya 
pendengaran pada telinga kanan, kemudian dianjurkan untuk menjalani terapi penyuntikan deksametason intratimpani sebanyak 4 kali $0,3 \mathrm{ml}(1,5$ $\mathrm{mg}$ ) selang 3 hari.

Prosedur penyuntikan sebagai berikut: Pasien tidur telentang dengan kepala diputar sekitar $30^{\circ}$ menjauhi telinga yang sakit, telinga dibersihkan, lalu dilakukan aseptik / antiseptik menggunakan betadin, kemudian dilakukan anestesi lokal menggunakan xylocain spray yang disemprotkan ke kapas gulung lalu dimasukkan ke liang telinga sampai ke membran timpani, dibiarkan selama 10 menit lalu kapas diangkat. $0,3 \mathrm{ml}$ deksametason $5 \mathrm{mg} / \mathrm{ml}$ disuntikkan ke kavum timpani melalui kuadran posterorinferior membran timpani menggunakan spuit $1 \mathrm{ml}$ dengan jarum no. 23G yang ujungnya dibengkokkan, dengan panduan mikroskop. Sebelumnya larutan deksametason dipanaskan sesuai suhu tubuh $\left(37^{\circ} \mathrm{C}\right)$. Setelah penyuntikan, posisi pasien dipertahankan selama 1 jam. Prosedur penyuntikan selesai, evaluasi respon pasien.

Pasien kontrol ulang setelah 1 minggu tindakan dengan membawa hasil audiometri, yaitu tuli sensorineural derajat berat dengan ambang dengar $77,5 \mathrm{~dB}$ (Gambar 5). Pasien merasakan pendengaran lebih baik dibandingkan sebelum diterapi, telinga berdengung berkurang, pusing berputar tidak ada, nyeri pada telinga tidak ada, keluar cairan dari telinga tidak ada. Tes penala didapatkan Rinne telinga kanan dan kiri positif, Weber lateralisasi ke kiri, Schwabach telinga kanan memendek dan kiri sama dengan pemeriksa. Pasien disarankan kontrol 1 bulan lagi untuk evaluasi perbaikan pendengaran, tetapi pasien tidak kontrol dikarenakan masalah pekerjaan. Evaluasi keluhan pasien melalui telepon mengatakan pendengaran sudah lebih baik dari kontrol terakhir.

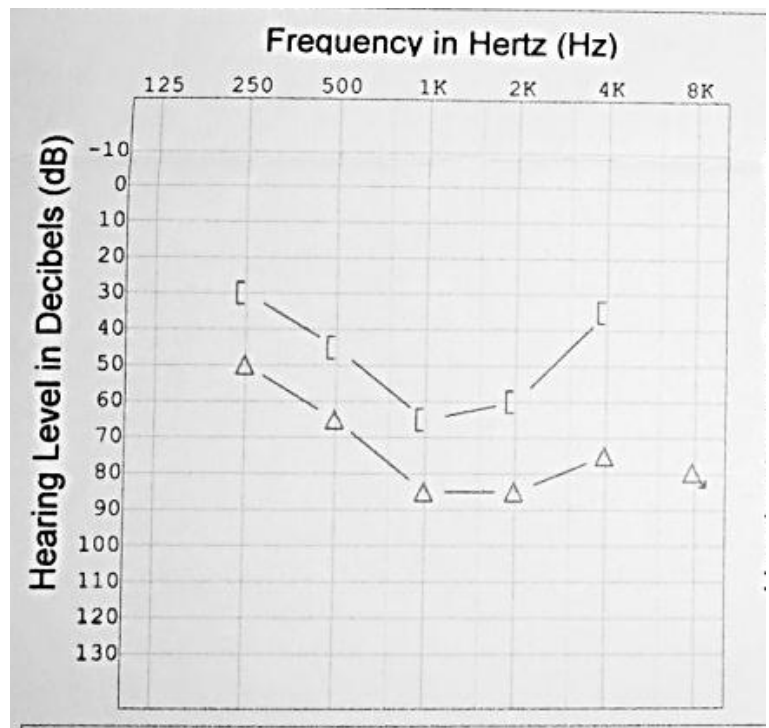

Gambar 5. Audiogram 1 minggu setelah tindakan, tuli sensorineural derajat berat dengan ambang dengar $77,5 \mathrm{~dB}$ pada telinga kanan

\section{PEMBAHASAN}

Telah dilaporkan satu kasus pasien perempuan usia 36 tahun dengan diagnosis tuli mendadak telinga kanan. Tuli mendadak dapat terjadi pada semua usia dengan usia rata-rata 50-60 tahun. Insiden pada laki-laki sama dengan perempuan.

Pada kasus ini pasien mendapat terapi kortikosteroid oral selama dua minggu kemudian dilanjutkan dengan terapi penyuntikan deksametason intratimpani sebanyak empat kali secara selang 3 hari, dikarenakan tidak terdapat perbaikan atau gagal terapi. Sebelum diterapi ambang dengar 103,75 dB setelah terapi kortikonsteroid oral menjadi 97,5 dB. Pasien ini menjalani salvage therapy, terapi penyuntikan deksametason intratimpani sebanyak empat kali, (selang 3 hari) dengan dosis $0,3 \mathrm{ml}$ deksametason $5 \mathrm{mg} / \mathrm{ml}$. Hal ini sesuai dengan yang dilakukan Wang pada penelitian di China. Besar dosis yang digunakan tergantung dari volume telinga tengah pasien sebesar 0,66 ml. Penelitian Zhou juga melakukan penyuntikan intratimpani sebanyak 4 kali secara selang hari tetapi dengan metilprednisolon. Efek samping penyuntikan yang dirasakan pada pasien adalah nyeri setelah penyuntikan, pasien mendapat terapi asam mefenamat $500 \mathrm{mg}$ bila nyeri. ${ }^{18,19}$

Penelitian Lim menyimpulkan bahwa antara terapi oral kortikosteroid, injeksi intra timpani dan terapi kombinasi memberikan hasil yang relatif sama, sehingga dapat digunakan sebagai terapi pertama dalam pengobatan tuli mendadak. ${ }^{20}$ Penelitian Lee menyimpulkan bahwa terapi kombinasi antara injeksi intra timpani dengan kortikosteroid siistemik lebih baik dari pada kortikosteroid sistemik saja. ${ }^{21}$ Sedangkan menurut Dispenza dkk menyarankan salvage therapy menggunakan injeksi deksametason intratimpani pada pasien yang mengalami kegagalan terapi pertama kortikosteroid sistemik. ${ }^{22}$

Pada pasien ini terdapat perbaikan pendengaran dibandingkan awal terapi kortikosteroid 4 minggu setelah tindakan sebesar 26,25 dB. Pada awal terapi 103,75 dB, 2 minggu setelah oral kortikosteroid tindakan 97,5 dB dan 2 minggu setelah tindakan terdapat perbaikan pendengaran menjadi 77,5 dB.. Menurut kriteria Siegel pasien ini termasuk perbaikan ringan. ${ }^{17}$ Menurut kriteria Kallinen : Baik, apabila rerata perbaikan 10-30 dB pada 5 frekuensi. Pada pasien ini masing masing frekuensi terdapat perbaikan $40 \mathrm{~dB}$ $(250 \mathrm{~Hz}), 35 \mathrm{~dB}(500 \mathrm{~Hz}), 35 \mathrm{~dB}(1000 \mathrm{~Hz}), 20 \mathrm{~dB}$ $(2000 \mathrm{~Hz})$, dan $25 \mathrm{~dB}(4000 \mathrm{~Hz}) \cdot{ }^{11}$ Sedangkan menurut Ho seperti yang dikutip oleh Filipo; pulih minimal dengan peningkatan ambang dengar sekitar 10-30 $\mathrm{dB}^{16}$ Pada pasien ini perbaikan ambang dengar $26,25 \mathrm{~dB}$.

Prognosis tergantung pada usia, onset kehilangan pendengaran, ada tidaknya vertigo, jenis audiogram pertama, respon 2 minggu pengobatan pertama, derajat ketulian, adanya tinnitus dan faktor predisposisi. Pasien ini berusia 36 tahun, dengan onset kehilangan pendengaran 2 hari, Tidak ada 
vertigo, tetapi terdapat tinitus. Derajat ketulian pasien ini menurut ISO adalah tuli sangat berat $(>90 \mathrm{~dB})$, yaitu $103,75 \mathrm{~dB}$, dengan tipe pendengaran menurut Atay adalah profound $(>70 \mathrm{~dB}$ pada masing-masing frekuensi). ${ }^{1}$ Mulai pengobatan pasien ini termasuk early treatment dikarenakan kurang dari 5 hari dari onset pertama.

Setelah terapi kortikosteroid sistemik dari ambang dengar 103,75 dB menjadi 97,5 dB, dengan makna tidak ada perbaikan dikarenakan peningkatan 6 dB. Setelah dilanjutkan dengan penyuntikan deksametason intra-timpani ambang dengar menjadi $77,5 \mathrm{~dB}$, terdapat peningkatan $20 \mathrm{~dB}$. Menurut Haynes keberhasilan injeksi intratimpani pada salvage therapy apabila terdapat peningkatan minimal $20 \mathrm{~dB} .{ }^{6}$ Pada pasien ini sesudah terapi terdapat peningkatan $20 \mathrm{~dB}$, dapat dikatakan bahwa terapi pada pasien ini berhasil.

\section{SIMPULAN}

Pemberian kortikosteroid intratimpani sebagai salvage therapy bermanfaat sebagai penatalaksanaan pada pasien tuli mendadak yang setelah pengobatan oral kortikosteroid gagal. Salvage therapy dikatakan berhasil apabila terdapat peningkatan minimal $20 \mathrm{~dB}$ setelah terapi

\section{DAFTAR PUSTAKA}

1. Atay G, Kayahan B, Cınar BC, Sarac S, Sennaroglu L. Prognostic Factors in Sudden Sensorineural Hearing Loss. Balkan Med J. 2016; 33:87-93.

2. Novita S, Yuwono N. Diagnosis dan Tata Laksana Tuli Mendadak. Cermin Dunia Kedokteran. 2013; 40(11):820-6.

3. Chau JK, Lin JRJ, Atashband S, Irvine RA, Westerberg BD. Systematic review of the evidence for the etiology of adult sudden sensorineural hearing loss. The Laryngoscope. 2010; 120.

4. Oliver ER, Hashisalri GT. Sudden Sensory Hearing Loss. In: Johnson JT, Rosen CA, editors. Bailey's Head \& Neck Surgery Otolaryngology. Otology. 2. 5 ed. Philadelphia: Lippincott Williams \& WJ.Ikins; 2014. p.2589-96.

5. Raymundo IT, Filho JB, Maia A, Pinheiro TG, Oliveira CA. Intratympanic Methylprednisolone as Rescue Therapy in Sudden Sensorineural Hearing Loss. Braz J Otorhinolaryngol. 2010; 76(4):499509.

6. Haynes DS, O'Malley M, Cohen S, Watford K, Labadie RF. Intratympanic Dexamethasone for Sudden Sensorineural Hearing Loss After Failure of Systemic Therapy. The Laryngoscope. 2006; 117:1-15.

7. Weber PC, Khariwala S. Anatomy and Physiology of Hearing. In: Johnson JT, Rosen CA, editors. Bailey's Head and Neck Surgery Otolaryngology. Otology 2. 5 ed. Philadelphia: Lippincott Williams \& WJ.IKins; 2014. p.2253-73.
8. Fedriani J. Steroid Intratimpani untuk Penanganan Tuli Mendadak. Cermin Dunia Kedokteran. 2015; 42(2):149-51.

9. Stachler RJ, Chandrasekhar SS, Archer SM, Rosenfeld RM, Schwartz SR, Barrs DM, et al. Clinical Practice Guideline: Sudden Hearing Loss. Otolaryngology-Head and Neck Surgery. 2012; 146(1S):1-35.

10. Soetirto I, Hendarmin H, Bashiruddin J. Gangguan Pendengaran (Tuli). In: Soepardi EA, Iskandar N, Bashiruddin J, Restuti RD, editors. Buku Ajar IImu Kesehatan Telinga Hidung Tenggorok Kepala dan Leher. 6 ed. Jakarta: Fakultas Kedokteran Universitas Indonesia; 2007. p.10-22.

11. Bashiruddin J, Soetirto I. Tuli Mendadak. In: Soepardi EA, Iskandar N, Bashiruddin J, Restuti $\mathrm{RD}$, editors. Buku Ajar IImu Kesehatan Telinga Hidung Tenggorok Kepala dan Leher. 6 ed. Jakarta: Fakultas Kedokteran Universitas Indonesia; 2007. p.46-8.

12. Battaglia A, Burchette R, Cueva R. Combination Therapy (Intratympanic Dexamethasone + HighDose Prednisone Taper) for the Treatment of Idiopathic Sudden Sensorineural Hearing Loss. Otol Neurotol. 2008; 29:453-60.

13. Lalwani AK, McGuire JF. Pharmacologic and Molecular Therapies of the Cochlear and Vestibular Labyrinth. In: Flint PW, Haughey $\mathrm{BH}$, Lund VJ, Niparko JK, Richardson MA, Robbins $\mathrm{KT}$, et al., editors. Cummings Otolaryngology Head \& Neck Surgery. Otology, Neuro-otology, and Skull Base Surgery 3. 5 ed. Philadelphia: Elsevier; 2010. p.2179-202.

14. Kasapoglu F, Tuzemen G, Hızalan I, Erisen L, Basut O, Onart S, et al. Prognosis in Sudden Hearing Loss: Is it the Disease or the Treatment that Determines the Prognosis? Int Adv Otol. 2009; 5(2):187-94.

15. Conlin AE, Parnes LS. Treatment of Sudden Sensorineural Hearing Loss. Arch Otolaryngol Head Neck Surg. 2007; 133:582-6.

16. Filipo R, Covelli E, Basalamo G, Attanasio G. Intratympanic prednisolone therapy for sudden sensorineural hearing loss: A new protocol. Acta Oto-Laryngologica. 2010; 130:1209-13.

17. Ferri E, Frisina A, Fasson AC, Armato E, GiacomoSpinato, Amadori M. Intratympanic Steroid Treatment for Idiopathic Sudden SensorineuralHearing Loss after Failure of Intravenous Therapy. ISRN Otolaryngology. 2011; 2012:1-6.

18. Kara E, Cetik F, Tarkan O, Surmelioglu O. Modified intratympanic treatment for idiopatic sudden sensorineural hearing loss. Eur Arch Otorhinolaryngol. 2010; 267:701-7.

19. Zhou $\mathrm{Y}$, Zheng $\mathrm{H}$, Zhang $\mathrm{Q}$, Campione PA. Early transtympanic steroid injection in patients with 'poor prognosis' idiopathic sensorineural sudden hearing loss. ORL. 2011; 73:31-7. 
20. Lim HJ, Kim YT, Choi SJ, Lee JB, Park HY, Park $\mathrm{K}$, et al. Efficacy of 3 Different Steroid Treatments for Sudden Sensorineural Hearing Loss: A Prospective, Randomized Trial. OtolaryngologyHead and Neck Surgery. 2012; 148(1):121-7.

21. Lee JB, Choi SJ. Potential Benefits of Combination Therapy as Primary Treatment for Sudden Sensorineural Hearing Loss. Otolaryngology-Head and Neck Surgery. 2016; 154(2):328-34.

22. Dispenza F, Stefano AD, Costantino C, Marchese D, Riggio F. Sudden Sensorineural Hearing Loss: Results of intratympanic steroids as salvage treatment. Am J Otolaryngol Head Neck Med Surg. 2013; 34:296-300. 